\title{
RELIGION AND SOCIAL CULTURE OF THE PEOPLE OF WEST KALIMANTAN'S PENATA ISLAND
}

\author{
D. Darmadi JA \\ Malay Corner of IAIN Pontianak
}

\begin{abstract}
The Penata Island, also called the Fishermen's Contact Village, exemplifies the Indonesian people's characters in general. These characters are preserved to this day in the village to reflect social behavior of the people as native culture of Indonesia, such as helping each other, a sense of community life, and work discipline. When they have problem, they are able to resolve it wisely through community leaders. When the problem is not resolved, it will be taken to the police and resolved through other legal ways. From the results of this study, the researcher saw a few things that have not been done properly, for example, the fishermen have yet to perform the five-time prayers. Some of them are involved in gambling and liquor-drinking, though it is a restricted case that does not have any influence on behavior patterns of the community members in general especially with regard to the practice of Islamic religious teachings.
\end{abstract}

Keywords: Religion, Social, Culture, Penata, Island and Islam

\section{INTRODUCTION}

The people of Indonesia have long been known for its wide range of cultural and social life. It is this nation's wealth that synergizes with the plurality, ethnicity, culture and religion where each ethnic or cultural group, and different religions will provide direction, guidance and guidelines for the social life of the people. According to Ibrahim, et al (2012), studies and research on socio-cultural society needs to be continued and expanded further, particularly on the Malay people and other ethnic groups generally as an effort to anticipate the loss of native cultural society in the middle of a range of threats and the influence of global freedom. In examining socio-cultural sphere, especially the maritime community, we must examine the empirical area that that becomes the community's character based on local wisdom. It should be noted that a conflict in a village or area is often due to cultural differences in the process of social interaction. It is then worsened since the process of social interaction is not accompanied by appreciation or respect for the local culture. The writer believed that local wisdom practiced by the island's coastal 
communities, i.e. fishing communities must continue to be preserved especially among the fishermen of the coastal islands, particularly in West Kalimantan, and generally in the Unitary State of the Republic of Indonesia.

The study focuses on the fishing communities on the Islands fishing communities with multi-ethnic and religious groups especially the sociocultural aspect. In addition, the multi-ethnic community has its own character, as a fishing community of the Penata islands. Such maritime study on sociocultural outlook is still very limited. The limitation is because experts are more interested in other fields like the study on economics and education. The seventh President of the Republic of Indonesia introduced his nawacita (nine objectives) which gave priority to the maritime potential, and it had a significant effect on awakening of the Indonesian maritime world. In this paper, the author will trace the social culture that flourished among the Islands people, precisely the community of Penata Island, Sungai Raya Subdistrict, Bengkayang Regency, West Kalimantan Province, Indonesia. This simple piece of writing, attempts to provide the philosophy of socio-cultural life because religion provides authentic cultural space which is spirituality. In short, the author seeks to describe the lives of socio-cultural aspects of Penata people from the theoretical study. This study is also a way of expanding our horizon on the social life of Indonesia from a cultural perspective on the the Islands people's daily life. Various social aspects of culture that thrive on the Penata island will be presented in this paper, such as gotong royong (shared community work), traditional ritual for the safety of the island, recitation of Al-Barzanji, wise advice, as well as various other community social aspects which deals with the socio-culture of a religious community.

To enrich the social conception of culture on the nation Indonesia, then it is important to examine the empirical conceptions of socio-culture thriving in a grass roots community. This is certainly very interesting to study as it provides reference to the conception of a socio-culture to anthropologists. In addition, this study focuses on coastal communitiesliving on the Islands based on local wisdom where a variety of socio-cultural aspects is still practices and preserved to this day. The socio-cultural concept applied in Indonesia is tends to be anthropological rather than philosophical. That is, the practice of social life is not directed toward humanitarian goals, but it is engineered for the sake of a political expediency in which socio-cultural process is often driven from the powerful, either the power of knowledge or the State. This is where the anthropological characteristics become vital because socio-cultural life requires replacement of norms at the level of people's behavior. Here we come into contact with evolutionism and functionalism in the form of a materialist 
perspective of socio-cultural aspects. At the level of culture, we have gone through various typology of cultural characters, either through structuralism and interpretivism, as in the study of ethics by Niels Mulder on Javase ethics and Clifford Geertz in sorting the three religions of Java. Williams (in Mudji Sutrisno and Hendar Putranto, 2005) argued that the historical changes could be reflected in terms of culture into three categories including 1) changes that refers to the development of intellectual, spiritual, and aesthetic traits of an individual, a group, or community, 2) changes that try to include intellectual activities and artistic treasures as well products produced (film, artistic objects, and theater), and 3) changes that describe the whole way of life, activism, beliefs, and customs of a number of people, groups, or communities.

Abdullah, Irwan (2009) explained that in a social environment, conflict and integration are equally managed in inter-ethnic social interaction. In order to take a look at the process of social interaction in a particular social setting, there are three important things to consider. First, the articulation of the existence of an ethnic group where the presence of other groups has to go through a process of insightfulness both by the ethnic group concerned and by others in a social environment. Second, the existence of a public space where inter-ethnic differences become weaker in the public space especially in the process of assimilation. In a certain public space, various ethnic groups will learn to communicate in a way more acceptable in general, and each group should learn to accept differences of the other groups (Green, 1995). Third, the symbols of inter-ethnic communication are the key in the process of assimilation. Symbolic human beings tend to live in the process of creating symbols and reading or interpreting the symbols in the process of social interaction. There is no doubt that these symbols will undergo a construction process that takes place in a dynamic manner.

The inter-ethnic socio-cultural life may share symbols and need to pay attention to a common understanding of those symbols in an inter-ethnic communication process. These cultural symbols belong to all groups and should be preserved when it is regarded as functional in fulfilling the groups' needs. Third, the three aspects above are considered important in explaining the process of assimilation that occurs in a particular social environment, especially for the islands communities. The social context in this case provides a framework and helps to form ethnic characters and the relationship between ethnic groups in the case of the dominant culture, social environment has an important influence in building a culture of communication in the process of inter-ethnic interaction. In line regard, the social environment has a historical background crucial to be studied and has an objective reality (Berger and 
Luckmann, 1991).

In an environment where multi-ethnic groups exist, there should certainly be a universal symbol that can be encoded or read, at least by nearly all ethnic groups. With this symbol, they can maintain an integrated social system. The symbols of communication are built together and preserved in a public space whose existence is also negotiated in a series of interactions. In the social interaction between ethnic symbols, each group actually absorbs and enriches cultural expressions of another group in a residential neighborhood. As a result, the differences do not always lead to inter-ethnic conflict, rather they have somehow enriched each other with mastery of language, personality development, insight, maturation, and social practices that are more colorful in terms of values. With this kind of context in mind, public relations should also pay attention to the fundamentals of social accommodation that allows assimilation to take place.

In an effort to revive local wisdom as a strategy of conflict resolution and peace-building, a cultural approach is often suggested by the media to explain the events of conflict. Culture is a factor that forms a group, allowing the group to have shared understanding of their identity, their origins, other things they share, and a general understanding of their shared objectives. Usually, this is a system of values and meanings expressed through language, symbols, rituals, gestures and traditions. Taking into account of several experts' opinions on socio-cultural in the previous discussion, we can have an understanding that it is important in social life to manage conflict and integration together in a social interaction particularly between different ethnic groups. Moreover, we need to continue to revitalize the indigenous culture that should grow and be sustainable under current society.

\section{THE PEOPLE OF PENATA ISLAND}

Penata Island is an exotic island, surrounded by other naturally beautiful outer islands that are amazing to see. In addition to its beauty, if we examine more in terms of the social and cultural life, the people of this island are unique particularly their closeness to the natural surroundings. The Penata Island people also have a high sense of solidarity in the community in various aspects and activities of daily life, one of which is the community work of making bagan.

The high sense of solidarity in the community illustrates the real character of the Indonesian people. These people who inhabit the island of Penata are migrants who come from different regions, ethnicities, and religions. Many of 
them come from Sulawesi, Sambas, Singkawang, Bengkayang, Sungai Pinyuh, Padang Tikar, and so on. They also come different ethnic groups, such as ethnic Chinese, Dayak, Bugis, and Malay. The People of Penata Island also belong to different religious groups i.e. Muslims, Christians, and Chinese Religion. Since their backgrounds are different, they often call themselves the inhabitants of Kampung Kontak Nelayan (Fishermen's Contact Village).

What Kampung Kontak Nelayan means here is that it is an island used as a temporary village as a stopover for fishermen of various ethnicities, religions, and regions of origin with the same goal of looking for sea products. Kampung Kontak Nelayan serves as the location for a making a living as well as a resting area. They have a house made of wood and there are only 3 to 4 permanent houses made of cement. The Penata Island average person has a permanent house in his native village. Administratively, the Penata Island residents have no identity card. They have an ID card of where they are from. Previously, the overall population of all ethnic groups on the Penata Island was 200 households. Currently, there are about 100 households. Between 1960-1965, there were still a lot of Chinese communities living on the island, especially on the west side of the island ( 5 families) and on the south with approximately 7 households. Until now, the island was used as a stopover as well as a place for making a living for the fishermen. In addition, Penata Island also serves as the Fishermen's Contact Village where they communicate, interact, establish good relationship and build the character of local culture together as the Penata people. They live side by side, peacefully, with the impressive spirit of togetherness.

\section{CULTURE OF HELPING EACH OTHER AND SENSE OF TOGETHERNESS}

The data in this study was obtained from interviews with an informant called Tagi '/Pak Aji (aged 55) on 26 October 2014 during a Kampung Research activities carried out by the State Institute of Islamic Studies (IAIN) Pontianak. From the results of these interviews, various socio-cultural activities of the Penata people were revealed. The activities of the Penata people have grown and developed into a culture that becomes a unique character of the people on the island. The characters will be presented as follows.

\section{Community work of caring for the Boat}

The fishermen rely on fishing boats to go fishing, for example, when they need to set up nets in the Bagan. Every afternoon before the evening comes, the fishermen go to the Bagan on their boat. As a means of transportation, the 
boat is used every day, so it needs to be well maintained. Care is required when the fishing boat is partly damaged, thereby disrupting the work to catch fish on Teluk Suak or around the Samudera Beach. It is common that the care for the boat is done before the arrival of transition season. The season can be forecast by the arrival of the monsoon season that hits in the west, north and east, which leads to the fishermen's bustle. The transition season may sometimes cause the bagan to be damaged, shatterred, broken and washed away, except the one in the south where the Bagan can still be installed. The transition season usually arrives between November to January. As it is impossible for the fishermen to go to the Bagan, the results from fishing activities are also not much. Therefore, the transition season is the right time to perform maintenance and repair the boats.

According to another informant, Bang Udin (aged 30), the boat maintenance includes servicing the engine and body of the boat, such as replacing the damaged belian or leban wood that serves as the pillar of the boat frame, hammering some nails to make it stronger, and replacing the keruin (adhesive), then painting the boat to the taste of the boat owner. The boat is usually towed to shore to be repaired. Members of the community come to work together on the boat. Mutual cooperation is done spontaneously when the residents of Fishermen's Contact Village saw or heard of a boat that needs maintenance. Then without any command, they will get together and jointly tow the boat to the shore. During my first time visiting the island, I joined the local people to tow a boat ashore. After the boat was towed ashore, people immediately went back to their own business, some stayed to help clean it.

The place for the maintenance facilities of fishing boats can be found in the Northern part of the Island, next to Tagi's house. Each day, one to two boats are normally repaired here. The repair period depends on the damage, taking two or three days to months. The time needed to fix fishing boats sometimes also depends on the owner, whether he is busy or not with his work taking care of the clove farm. After fixing the boat, the residents of Kampung Kontak Nelayan will gather to help the owner of the boat lower the boat back onto the sea. The boat owner sometimes only says thanks to the people who have helped him, sometimes he also provides free cigarettes. When the work is completed, residents will disperse spontaneously usually accompanied by laughter and puff of a cigarette as a sense of satisfaction. To tow the boat ashore and to take it back to the water usually requires some tools such as ropes, axes, machetes, and wooden girder. As soon as the boat is back on the water, the owner will check for leakage or any equipment left behind or parts of the engine not installed. When all the problems are solved, the boat is ready to go back to be 
used as a primary means of transportation in fishing activities.

\section{Boiling the Catch}

Based on the author's observations, the sense of togetherness is also practiced in the communities of Penata Island especially boiling fish caught from the Bagan. The catch is in the form of fish and cuttlefish boiled in the Paon belonging to fishermen who have returned from the Bagan. The togetherness is evident from the solidarity of the fishermen when the catch is not much, only about one to two baskets. They will come to boil fish or cuttlefish in the paon owned by fishermen who have returned earlier. Helping each other in boiling the catch has already become a tradition for the fishing communities on the island, so no pay is required. The point is simple that when one needs help, others will come to do the favor. When the catch is only a little, the fishermen usually boil the fish at a neighbor's place.

Based on the observations and the interview with the respondents, the tradition of helping each other in boiling the fish caught is done to save firewood because they usually buy the firewood purchased from Teluk Suak to boil the fish and cuttlefish in the Paon. Teluk Suak is a port that also serves as a place for the fishermen to shop for groceries and sell the catch. Teluk Suak port is also used to ferry up and down (home and away) to the nearby islands, such as Lemukutan, Penata, Kabung, Randayan and other islands. At the Teluk Suak, firewood is sold for boiling fish in the Paon. The price of firewood is around IDR 700-800 thousand for one truck, so it is quite expensive for the islands fishermen. The attitude of helping each other in the daily activities among the islands community provides us with an example of the importance of solidarity in life. This character unfortunately has faded in urban communities where people tend to live without thinking about the burden of others, let alone reducing the suffering of the neighbors. We should take example of the character of the Penata Island community in mutual assistance to ease each other's burden of life.

\section{Sharing unconditionally}

This part will explain about other habits of people of Penata island especially the way they share fish unconditionally to the neighbors. For example if we want to eat fish or cuttlefish, we can simply ask for some to the owner. They think it is all right to take some of the catch for eating. For the residents of Fishermen's Village and guests, taking some fish for everyday dish, especially certain fish species like sardine. As reported by Bastian (50 years), the above 
habit was apparently the truth. This was proved during our research activities on the island where we never bought side dish. The Penata Island residents offered us some fish or cuttlefish from their catch which was still fresh or already dried. They even sometimes directly put some into a plastic bag not only to be eaten at the location during research activities, but also to bring back to Pontianak. For us as guests, the hospitality we showed to the fishermen somehow also contributed to their generosity. It was fun to choose a side dish we wanted to have be it small fish, cuttlefish, sardine and so forth. Bastian (50 years) further revealed that the habit of sharing is done with sincerity. In addition, they also believe with sincerity, they will certainly maintain good relationship and be rewarded by Allah especially during their trip to the sea to catch fish at the Bagan.

\section{CONNECTING TO TELUK SUAK AND SOME CULTURAL ACTIVITIES}

Going back and forth to the Teluk Suak port is done by the fishermen for the purpose selling their catch and shopping for their daily needs. The catch of the fishermen in Kampung Penata Island is sold for cash and partly for logistics and maintenance of fishing equipment. Among the merchandise they buy: gasoline, diesel, lights, and nets. The logistics for supplies they buy such as cigarettes, sugar, rice, cooking oil, spices and pastries, as well as other things according to their needs. As a comparison, in Labuhan Haji, Pelapis Islands, North Kayong, we can find a community of fishermen who sell their catch to purchase logistics such as diesel fuel, nets, rice, sugar, cooking oil, etc. I need to explain that the meaning of the word naik (going up) means departing from the Penata Island to the port of Teluk Suak or Smaudera Beach. The fishermen took their catch with them i.e. dried anchovies and cuttlefish. When they "go up", they not only go to the port, but some fishermen also go to Singkawang or elsewhere. They do this to visit their home and to see their children who leave for school, to shop or to do other things.

While the word "come down" means the fishermen return from the port of Teluk Suak to Penata Island or other islands. This normally done after all they have done all their business. They usually leave for the port early, and in the afternoon they return to the Island. Most of the time they go down or return to the island before the "working hour" starts (going to work) at the Bagan, which is around 4 o'clock in the afternoon. At first, we thought when the people of Penata Island go back and forth from the island to Teluk Suak, they need to pay for transportation fees. Apparently, they can simply come with the owner of the ship. Even though their life on the island is a little "hard", they are very 
generous. So, when there are people going back and forth, other can simply join them and save some money. That's how we should live, helping each other.

\section{Selamatan Pulau}

The cultural activities such as selamatan Pulau (ceremony held for safety of the island) have magical powers to build good ethnic relations. Usually this kind of cultural event involves various ethnic groups, women, youth, and children. With cultural activities, they achieve mutual understanding between ethnic groups. The selamatan tradition has already been on island since long ago, and has become a culture which is passed down from their ancestors. It is unknown as to when it was held and who held it first. According to information obtained from an informant, named Tagi /Pak Aji (aged 55), the Selamatan culture was passed down by the Malays who came from Sambas. The Malay are Muslim, speak Malay, and practice Malay customs. In the context of the culture, the owner of the Selamatan culture is the Malay originating from Sambas area with Sambas Malay language and Sambas Malay customs.

In fact, administratively, the Penata Island and surrounding islands were part of the territory of the Kingdom of Sambas. However, in recent years the islands have become part of Bengkayang Regency and Singkawang City. In the past, the two districts and the city of Singkawang belonged to the Sambas Regency. The proof that the Penata Island and other islands around it were part of the Kingdom of Sambas was the primary language used by the people on the island which is Sambas Malay, even no matter if they are Bugis and Chinese by ethnicity. The Selamatan pulau is the custom or tradition that is performed when you first set foot in Sambas. "We follow the custom of Sambas," said Tagi. It is an attempt to honor people who first occupied these islands. As long as it does not violate the religious law of Islam, it is not wrong to hold this ceremony. We just leave everything that we do to Allah Almighty. All processes are carried out, including giving offerings through an intermediate as a form of gratitude to nature as part of God's creatures.

The question that needs to be answered is why do the Sambas Malay inherit the tradition of Selamatan? The answer is because the Penata Island was first settled by the Sambas Malay hundreds of years ago who came from the Sambas Kingdom (informant: Tagi ‘/ Pak Aji, aged 55). Proof of the Malays as the earliest inhabitants of the Penata Island can be seen from the ownership of the coconut plantation which is estimated to be hundreds of years of age. The coconut farm has been owned for generations until today by the Sambas Malay. Decades later the Chinese and people from Sulawesi especially from Buton and Bugis came to the island. Today, the Penata island is inhabited by 
the Malays, Bugis, and Chinese. The tradition of the selamatan pulau can be understood as a ritual activity of the Penata Island people to ask for safety and abundant results from fishing (interview with Tagi//Pak Aji, 55 years old). This tradition has become the hallmark of a society that inhabits the coastal areas of the Island. Often the respect for the nature or the universe is expressed with the various ritual and spiritual processions. This tradition also suggests the closeness of nature surrounding the islands people.

The selamatan pulau is usually held around the seventh month (July) until the eighth month (August) every year. It is clear why it is held in those months. I personally think that between July and August, the sea is usually calm and the wind is not blowing too hard so the results of the fishing activities will be abundant. In carrying out the traditions of selamatan pulau, the people on the island usually celebrate by serving lamb as food. They never serve beef. If lamb is not enough, they add some chicken. During the celebration, lamb and chicken are considered quite exceptional. Fish is is not served either as they normally have it on a daily basis, and vegetable is seldom found on the island, if any, it is purchased from Teluk Suak, such as like cabbage, long beans, carrot and so on.

\section{Recital of the Qur'an and the Barzanji}

According to the informant Bastian (aged 56), in the past the Qurran recitation from house to house was often held. However, this is no longer in practice because there is no one to lead them. Previously, a Qur'an teacher of Sambas, Rachmawati was invited to do the job. In addition to learning to recite the Quran, the people on the island of Penata also had a tradition of reciting the Barzanji (panegyrics of Prophet Muhammad). The tradition of reading the Barzanji is held in events such as celebrating the tradition of selamatan pulau. The tradition of reading Al-Barzanji was conducted in turns, depending on who had the intention, sometimes conducted in the northern region of the island, the eastern region, and the western region. The reading activities was usually led Salim, who also became leader in the daily five time prayer. The traditions of the recitation of the Qur'an and reading AlBarzanji have now begun to disappear. The main reason according to the informant is because there is nobody to lead the activities anymore. Salim, the person who led the reading of Al-Barzanji is busy taking care of his sick wife and working to catch fish. Most fishermen on the Island work at the Bagan, processing the catch, and preparing to go back to the sea. 


\section{WISE ADVICE ABOUT LIFE ON THE PENATA ISLAND}

The Penata Island people have high respect for parents. Parents become a key figure in the everyday life of the people on the island. Since there is no structure of Hamlet or neighborhood association, the important figures on the island become supervisors and policy makers. The following is a glance at some of the key figures on the island. In the 1980s there was an important figure named H. Tanra> (the late). He was highly respected because of his wealth. As a wealthy person, of course, he left a lot of estate such as land and farms. As reported by his heirs, the land where the mosque is located now in the East up to the Tagi's house belonged to H Tanra. In fact, Tagi> also bought the land where his house is built on from the late H. Tanra' for IDR 5 million. It was purchased from his wife at Karimunting.

There was also another figure here named, H. Karim (deceased). He was like an elderly leader whose responsibility was to resolve various problems that occurred in this village such as conflict about permission to build the bagan, disputes between residents, and so on. On the Western part of the island, there is a figure named Mahli (aged 60). Mahli is an ethnic Malay originated from Sambas. The researcher travelled directly to his home. The location of his house is on Western tip of the island. It is the only house in the area. His neighbors are Bugis and Chinese people. Previously, Mahli worked for a Chinese person to care for the bagan. Now he has hiw own bagan, so with evry he gets, he will take it to the Chinese person who had once helped him. There are many Bagans belonging to Mahli. The condition is a bit old but they are not far from his home, can be reached using a small fishing boat. When we saw Mahli drying fish and cuttlefish from his catch the night before, the writer and Bang Erwin participated and tried to dry some anchovies and cuttlefish on a small mat approximately $30 \mathrm{~cm}$ x $50 \mathrm{~cm}$ in size.

The writer was amazed at the persistence of Mahli, as he is not young anymore but is still working hard to take care of the bagan to make a living for his family in Sambas. Around his House there are several fruit trees, such as mango, banana, and papaya. There is another important figure known by the name of Yusuf. As reported by Tagi ', Yusuf comes from Suak Village, sub-district of Sungai Raya Islands, Bengkayang District. He has a lot of relatives in Teluk Suak and certainly know many people there. Yusuf's role in the community is crucial as he usually deals with the village authorities and takes care of various other matters. He is originally a native of Kampung Suak, a small not far from the Penata Island.

Teluk Suak Village is well known and synonymous with its port as it is very strategic. The port is busy serving up the people of the island 
with various purposes including serving as a gate for tourists who will be visiting various islands around the Island, such as Penata Island, Lemukutan Island, Randayan Island, and other islands. In the northern part of the Penata Island to the east, there is also a figure name Tagi . His role and existence are always highly anticipated and respected by the people of the island. He always reminds the residents that the Fishermen Contact Village should hand-in-hand resolve problems or look for a way out. In fact, recently he reprimanded a fisherman who stored his catch at the mosque. Thank God, the fisherman listened to what he said, and promised not to do it again.

Until now, Tagi's role as a community leader is very important. He is capable of becoming the keeper of the harmony between the island's ethnic groups. $\mathrm{He}$ is also known for his sense of humor and does not hesitate to joke with people younger than him, though he may look unruly with his thick mustache, in actuality he has a big heart. During my stay at the research site, some time ago, I often chatted with him and some other people also joined over some coffee and cake at the paon belonging to Tagi'. The figures mentioned above, such as Tagi' and other figures are crucial in playing a role in maintaining harmony, order, and peace in the village of the Penata Island. In addition they also serve to ensure socio-cultural and religious values amongst the people are observed. In the future, there must be a successor to these figures that set a good example for the younger generation on the Island.

The people on the Penata Islands have wise advice that they keep alive as basic principles in life. These principles are very important and meaningful. In my opinion, the principles contain deep philosophical meaning that they use as a guide to struggle for a better life in the region. The principles, in the form of wise advice passed down from the ancestors, range from social, economic, educational, family matters to religion. The advise is preserved until today. The following will be displayed in sederhanaterkait various tips that people use the Penata Island. Wise advice that is commonly heard among the people on the island is "Dimana bumi dipijak, disitu langit dijunjung" which literally means "Wherever ground is stood on, the sky is hold high, meaning: Wherever we live, we must observe the local custom (equivalent to when in Rome, do as the Romans do --informant: Tagi') Most Indonesians know this saying, let alone the Malay as it is derived from the Malay culture.

Mr Tagi' gave another advice: «once banned, it remains banned; once told, never ban it". This tip intends to tell parents to be consistent in educating their children. When parents forbid their children to do something, they themselves should set an example such as drinking, gambling, and the like. Basically, it means that parents should be consistent with what they 
say. Conversely, any acts parents tell their children to do, such as asking his son to work at the Bagan, they should never prohibit their son to go to the Bagan. So consistency of attitude and behavior of parents in educating their children is very important, as children will surely listen and imitate everything taught or exemplified by their parents.

There is also another advice according to Tagi " that in educating children, parents should do it first. For example, when parents ordered their children to say prayer five times day, then the parents should provide examples. The words and the deeds should be in consistency. This principle is important in life, especially when educating the children in the household. Bastian (aged 50), an informant who is also one of the community elders, also gave an account of the principle in his life, i.e. to share and help each other. According to him, when we share with and help others sincerely, God will reward us with more returns. The principle of life is always is practiced when doing his job on the island or when wandering out of his territory. Based on the work of Sumama (2014), some other principles were reported about life on the Island. These principles include "better to quit school than to quit reading the Qur'an (interview with Tagi «). The principle of life stresses on the importance of religious education within a family, especially among the Bugis people on the Island.

However, in my opinion, education in the sense of formal education is very important because it is a fast way of transforming human civilization, from poverty to prosperity, from ignorance to enlightenment. On the other hand, religious education serves as the balancing aspect of human life. Religious education is also beneficial for the success of human life in the world and in the hereafter. According to Firman (an informant, aged 23), the principle in his life is "Forgetting about his dreams for the sake of helping letting his younger siblings to go to school". He is ready to sacrifice his ideals so that his brothers and sisters could enjoy high education because his parents are already old. There is saying among the Bugis people, "Don't get married before circling the kitchen seven times" (interview with Tagi's wife). The purpose of this advice is that marriage is likened to various seasonings in the kitchen. Chili is spicy, salt salty, sugar sweet, vinegar sour, and so on. According to the Bugis people the kitchen symbolizes marriage in real life as marriage has ups and downs.

The number 7 means that there are seven levels or the terms of which must be understood before starting your own family. First, mental readiness; second, the maturity of thought; third, understanding of the responsibility; fourth, ability to become a leader; fifth, ability to be wise; sixth, ability to be a good role model; seventh, ability to be a consistent person. A description of the range 
of advice used as the principles of life among the people of Penata Island mentioned above, can be regarded as non-formal education for the fishing communities on the Penata Island. Cultivation of noble character and behavior through the advice is passed down from parents to their children from generation to generation of the maritime community.

\section{CONCLUSION}

The Penata Island, also called the Fishermen's Contact Village exemplifies the Indonesian peopless characters in general. These characters are preserved to this day in the village to reflect social behavior of the people as native culture of Indonesia, such as helping each other, a sense of community life, and work discipline. When they have problem, they are able to resolve it wisely through community leaders. When the problem is not resolved, it will be taken to the police and resolved through other legal ways. From the results of this study, the researcher saw a few things that have not been done properly, for example, the fishermen have yet to perform the fivetime prayers. Some of them are involved in gambling and liquor-drinking, though it is a restricted case that does not have any influence on behavior patterns of the community members in general especially with regard to the practice of Islamic religious teachings. Hopefully, this simple research will be able document a description of socio-cultural life of the fishermen, especially on the Penata Island. It is also expected that readers can take a lesson, so that the nation's children will inherit the real Indonesian peopless characters, in the form of local wisdom and to put it into practice today and in days to come.

\section{REFERENCES}

Abdullah, Irwan. 2009. Konstruksi dan Reproduksi Kebudayaan. Pustaka Pelajar: Yogyakarta.

Amirrachman, Alpha (ed.). 2007. Revitalisasi Kearifan Lokal. Jakarta: International for Islam and Pluralism (ICIP).

Arif, Syaiful. 2010. Refilosofi Kebudayaan, Pergeseran Pascastruktural. Jogjakarta: Ar-Ruzz Media.

Atok, Kristianus, dkk. 2006. Merajut Damai, Pembelajaran Dari Promosi Pluralisme dan Perdamaian di Bumi Kalimantan Barat. Pontianak: Grahafika Utama Press.

Darmadi, Didi, dkk. 2013. Serba-Serbi dari Pulau,Catatan Perjalanan Tim 
kampung Riset P3M STAIN Pontianak ke Dusun Besar dan Pelapis Kayong Utara. Pontianak: STAIN Pontianak Press.

Ibrahim MS, dkk. 2012. Pantang Larang Melayu di Kalimantan Barat, Kajian Kearifan Komunikasi dalam Pantang Larang Melayu di Nanga Jajang Kapuas Hulu. Pontianak: IAIN Pontianak Press dan Malay Corner STAIN Pontianak.

Ruslan Ismail, dkk. 2015. Laporan Kelompok Kerja Sistem Nasional Pemantauan Kekerasan (SNPK) Kalimantan Barat. Kerjasama Habibie Center Jakarta, ELPAGAR, dan Kelompok Kerja SNPK Kalimantan Barat.

Sumama. 2014. Kehidupan Nelayan di Penatah Kecil. Pontianak: IAIN Pontianak Press.

Yusriadi. 2009. Memahami Kesukubangsaan di Kalimantan Barat. Pontianak: STAIN Pontianak Press.

\section{INFORMANS:}

Pak Bastian (50 tahun)

Bang Yos, 36 Tahun).

Pak Tagi'/ Pak Aji, 55 tahun).

Bu Tagi'/ Nirwana 2014.

Bang Jabir (25 tahun)

Bang Udin (30 tahun)

Pak Mahli (60 tahun) 
